\title{
Perundungan Reaktif di Sekolah Dasar dan Intervensi Berbasis Nuansa Sekolah
}

\author{
Arina Mufrihah ${ }^{1}$ \\ Prodi Bimbingan dan Konseling, STKIP PGRI Sumenep
}

\begin{abstract}
Parents and teachers have not known much that actually behavior of naughty children in elementary school is included violence behavior or known as bullying. Prevalence of the violence behavior which has happened, lack of attention and professional handling for violence behavior in elementary school were important reason to do this study purposely for: (1) indentifying who bullies, who gets bullied, and the content of the violence behavior; (2) explaining the differentiation of violence behavior beetwen two of gender student and beetwen higher class and lower class of elementary school student; (3) finding the risk factors are strong predictors of school environment violence; and (4) how does the teacher intervention to stop bullying. This research was worked by mixed method with explanatory design (quantitative $\rightarrow$ qualitative) and took 142 students as sample were gotten by using cluster sampling technique. Research finding showed as many as $62.761 \%$ students have ever acted violence behavior and there were difference violence act beetwen both of gender students $(P$ value $0.930>0.05)$ and also difference violence beetwen high class and lower class students ( $P$ value $0.930>0.05$ ). The risk factors of violence behavior at elementary school student were not merely family and school factor, but psychological factor also.
\end{abstract}

Keywords: bullying in elementary school, intervention of bullying, violence behavior.

Abstrak. Orang tua dan guru belum banyak menyadari bahwa "perilaku nakal" anak usia sekolah dasar sebenarnya juga merupakan perilaku perundungan. Melihat hal tersebut masih terjadi dan kurang mendapatkan perhatian atau penanganan serius terhadap perilaku kekerasan di sekolah dasar, maka penelitian ini dilakukan untuk mengidentifikasi pelaku, korban, dan bentuk kekerasan, menjelaskan perbedaan perilaku kekerasan antara siswa laki-laki dan siswa perempuan; antara siswa kelas rendah dan siswa kelas tinggi; menemukan faktor penyebabnya; dan bagaimana peran guru secara preventif dan kuratif terhadap perilaku kekerasan. Penelitian dilakukan dengan desain mixed-method berurutan (kuantitatif $\rightarrow$ kualitatif), jumlah sampel 142 siswa yang didapatkan dengan cluster sampling. Hasil penelitian menunjukkan bahwa sebanyak $62.761 \%$ siswa pernah melakukan tindak kekerasan dan terdapat perbedaan perilaku kekerasan antara siswa kelas rendah dengan siswa kelas tinggi ( $P$ value $0.930>0.05$ ), juga perbedaan antara siswa laki-laki dengan siswa perempuan ( $\mathrm{P}$ value $0.930>0.05)$. Faktor penyebab perilaku kekerasan bukan hanya keluarga dan lingkungan sekolah, namun juga diri sendiri, di mana para guru sudah melakukan upaya preventif dan kuratif terhadap perundungan berbasis nuansa sekolah.

Kata kunci: perundungan di sekolah dasar, penanganan perundungan, perilaku kekerasan.

\footnotetext{
${ }^{1}$ Korespondensi mengenai isi artikel ini dapat dilakukan melalui: arinamufrihah@gmail.com
} 
Sekolah dasar merupakan lembaga sosialisasi terkuat dalam perkembangan manusia. Entah baik atau buruk, sebagian besar masyarakat secara simultan membawa momen-momen penting sekolah dasar selama rentang kehidupannya (Gibson \& Mitchell, 2010). Sekolah Dasar di lain sisi menjadi lingkungan tempat terjadinya aksi kekerasan. Karena perilaku terbentuk berdasarkan modeling yang didapatkan dari lingkungan, baik sosial maupun non-sosial (Taylor, 2006), tidak terkecuali perilaku yang tidak sesuai. Terlebih periode SD adalah masa krusial bagi anak untuk berpartisipasi dalam kelompok teman sebaya (Veenstra, dkk., 2013). Sementara itu, krusialitas kelompok teman sebaya semakin banyak mendapat perhatian karena merupakan salah satu sumber terjadinya peer victimization.

Kekerasan di sekolah merupakan segala bentuk perilaku agresif untuk menyakiti orang lain seperti perundungan, kekerasan seksual, penyalahgunaan aktivitas seksual, dan berbagai perilaku siswa yang mengacu pada sikap bermusuhan pada sesama siswa dalam lingkungan sekolah (Sciarra, 2004). Kemudian Beattie (2015) menerangkan bahwa perundungan merupakan penyalahgunaan kekuatan secara sistematis dan dikategorikan sebagai perilaku agresif yang dilakukan oleh teman sebaya yang melakukannya secara berulang dan ditandai dengan adanya kekuatan yang tidak seimbang/setara (korban memiliki kelemahan dalam membela diri). Jadi perundungan di sekolah adalah bentuk dari perilaku agresif yang dilakukan secara berulang untuk menyalahgunakan kekuatan oleh teman sebaya di lingkungan sekolah.

Perilaku perundungan dapat berupa fisik (pukulan, tendangan, gigitan, dorongan, cekikan) atau verbal (penamaan yang buruk, ejekan/celaan, olokan, ancaman, menyebarkan rumor yang tidak menyenangkan), keduanya merupakan bentuk dari perundungan secara langsung. Sedangkan bentuk perundungan tidak langsung berupa menunjukkan sikap yang tidak bersahabat, menunjukkan raut muka bermusuhan, atau menjauhkan korban dari kelompoknya (Sciarra, 2004). Dalam kajian kesehatan mental, perilaku menyakiti orang lain tidak bisa dianggap remeh karena perilaku tersebut termasuk bagian dari conduct disorder (Morcillo, dkk., 2015; Notosoedirdjo \& Latipun, 2007).

Perundungan dan peer-victimization sebagai tindak kekerasan merupakan masalah yang banyak terjadi di SD dan telah menjadi public and mental health concern dan safeguarding issue (Beattie, 2015; Hong \& Espelage, 2012; Golmaryami, dkk., 2016), bahkan fenomena ini semakin meluas dan bertambah (Majcherova, dkk., 2014). Hampir setengah dari siswa pernah mengalami perundungan selama masa sekolah; setidaknya $81 \%$ siswa laki dan $72 \%$ siswa perempuan dilaporkan mengalami perundungan di sekolah (McAdams \& Schmidt, 2007). Dalam hal perundungan siber pun, didapati bahwa laki-laki lebih banyak melakukan perundungan dibandingkan perempuan (Ramdhani, 2016). Hal ini menjadi perhatian para pendidik, profesional, dan bahkan dunia karena hasil studi membuktikan bahwa perundungan berhubungan dengan outcome negatif pada anak sekolah dasar seperti masalah kesehatan personal distress, rendahnya prestasi akademik, rendahnya self-esteem, depresi, kecemasan, dan masalah kesehatan mental serius lainnya (Juvonen \& Graham, 2014; Olweus \& Breivik, 2014; Morrow, dkk., 2014; Puhl \& King, 2013; Beattie, 2015; Golmaryami, dkk., 2016). 
Korban perundungan umumnya merupakan siswa yang dianggap lebih lemah dalam pembelaan diri dan kurang mendapatkan dukungan sosial dari teman-temannya. Siswa korban perundungan memiliki sedikit teman sebaya dan mendapat lebih banyak reactive agression (Healy, dkk., 2015). Empat karakteristik dari siswa yang beresiko menjadi korban penganiayaan ialah siswa yang tidak memiliki keterampilan pertahanan diri, terlihat tidak dapat membela dirinya sendiri, memiliki peran yang lemah dalam aturan main kelompok teman sebaya, dan sekolah yang sepertinya menyediakan tempat yang kondusif untuk melakukan aksi kekerasan dan penganiayaan.

Umumnya, apa yang terjadi antar siswa hanya dianggap sebagai kenakalan biasa yang sewajarnya dilakukan oleh anak-anak. Menjadi korban kekerasan masih dipandang sebagai hal yang wajar, padahal faktor resiko juga dapat terpapar pada korban seperti terganggunya kesehatan mental dan fisik dan juga berdampak pada penyesuaian diri ketika dewasa (Beattie, 2015). Pengalaman traumatis di masa kanak-kanak terprediksi menjadi penyebab masalah yang akan datang. Sejumlah 3.692 anak-anak usia 710 tahun dilaporkan telah menjadi korban penganiayaan dan mereka menunjukkan masalah di awal usia remaja (11-14 tahun) berupa simptom masalah emosional dan depresi (Zwierzynska, dkk., 2013). Hasil penelitian mengindikasikan bahwa baik pelaku maupun korban secara tersendiri berhubungan dengan timbulnya masalah perilaku dan lemahnya kontrol emosi (Golmaryami, dkk., 2016).

Dalam fenomena perundungan tidak hanya terdapat korban saja (pure victim) dan pelaku saja (pure violence subject), namun juga terdapat korban-pelaku perundungan. Korban-pelaku merupakan istilah yang digunakan bagi siswa yang melakukan perundungan terhadap siswa lain dan mendapatkan perundungan dari siswa lain. Siswa SD lebih banyak melakukan kekerasan fisik dan verbal; korban-pelaku lebih sering menjadi target perilaku kekerasan dari dibandingkan pure-victims dan berkontribusi terhadap faktor tingginya perilaku maladjustment (Yang \& Salmivalli, 2013). Korban-pelaku dan pure victim secara konsisten berhubungan dengan sejumlah masalah kesehatan mental yang serius, berimplikasi pada personal distress, dan berlawanan dengan emotional well-being. Atas dasar itu perundungan harus segera mendapatkan penanganan oleh berbagai pihak dan pentingnya mengembangkan mekanisme penanganan kekerasan penganiayaan dari permasalahan kekerasan yang telah terjadi (Olweus \& Breivik, 2014).

Korban-pelaku ditandai dengan buruknya regulasi diri dalam fungsi kognitif dan behavioral, sementara yang menjadi korban saja menunjukkan agresi yang berkaitan dengan bias dalam proses sosial-kognitif namun tidak mengalami masalah penyesuaian diri, dan passive victim ditandai dengan perilaku yang tidak asertif dan memiliki keterampilan sosial yang rendah (Toblin, dkk., 2005). Baik perundungan cyber maupun perundungan tradisional, korban-pelaku secara signifikan memiliki agresi yang reaktif dan proaktif dibandingkan dengan pelaku saja (Burton, dkk., 2013).

Korban, pelaku, dan korban-pelaku di SD adalah siswa laki-laki dan juga siswa perempuan (Sciarra, 2004). Sejumlah 179 siswa kelas 5 baik laki-laki maupun perempuan secara berulang setiap hari melakukan kekerasan terhadap teman sebaya dan mengakibatkan dampak negatif terutama terhadap prestasi akademik. 
Terdapat lima bentuk kekerasan yang dilakukan, yaitu: kekerasan fisik, verbal, manipulasi sosial, perusakan benda, dan penolakan sosial (Morrow, dkk., 2014). Dari total 113 siswa SD berusia 6 hingga 10 tahun di Italia ditemukan bahwa sifat-sifat maskulin diprediksi berhubungan dengan perilaku perundungan aktif (Gini \& Pozzoli, 2006).

Studi yang dilakukan Veenstra, dkk. (2013) terhadap 2.135 siswa di tingkat 1 dan 2 SD menunjukkan siswa laki-laki lebih banyak melakukan kekerasan baik terhadap teman perempuan maupun lakilaki dibandingkan pelaku yang berasal dari siswa perempuan. Pelaku kekerasan selalu memilih target teman sebaya yang dipandang memiliki potensi untuk diancam dan pelaku selalu memilih korban yang secara sosial ditolak oleh teman sebaya. Siswa laki-laki lebih sering melakukan kekerasan dibandingkan siswa perempuan dan siswa laki-laki juga lebih stabil dibandingkan siswa perempuan dalam posisi korban kekerasan (Camodeca, dkk., 2002).

Selain lingkungan sekolah, keluarga juga memiliki peran utama, maka permasalahan perundungan oleh siswa adalah juga akibat dari rendahnya keberadaan anggota keluarga, mengabaikan pengasuhan dan pendidikan yang sepantasnya, penggunaan waktu luang yang tidak tepat, pelemahan lingkungan keluarga yang tidak mendukung pendidikan moral dan emosional bagi anak (Majcherova, dkk., 2014). Penelitian terhadap 1.271 anak Puerto Rico berusia 10 tahun, menyumbang data bahwa perundungan di sekolah bukan hanya faktor lingkungan sekolah namun juga disebabkan faktor kontekstual seperti keluarga, sosial, dan kultural yang seharusnya menjadi sasaran program intervensi (Morcillo, dkk., 2015).
Perundungan di antara teman sebaya juga menjadi masalah serius di sekolahsekolah di Tiongkok. Tiongkok yang memerlukan strategi pencegahan dan intervensi yang efektif. Studi menunjukkan bahwa peran orang tua, teman sebaya, dan guru dapat membantu atau mengurangi perundungan dan peer victimization di kalangan anak-anak SD (Huang, dkk., 2013). Terdapat cyclical process antara faktor resiko dan victimization sehingga intervensi pada kekerasan penganiayaan perlu mencakup penanganan stigma sosial, mengawali protective factor, mendesain pendekatan berbasis nuansa sekolah (Juvonen \& Graham, 2014), dan diperlukan pemahaman terhadap ekologi sosial (Hong \& Espelage, 2012). Healy, et, all. (2015) menyajikan data bahwa sampai saat ini hanya terdapat model reduksi kekerasan di sekolah, namun tidak melibatkan peran orang tua yang memiliki peran penting dalam perilaku pengasuhan anak karena berdampak pada perkembangan kompetensi sosial.

Dedousis-Wallace, et, all. (2014) menyarankan agar dalam penanganan kasus perundungan di sekolah guru lebih fokus pada perasaan korban sehingga mendapatkan solusi yang efektif. Peran konselor atau pembimbing di sekolah sangat vital untuk membantu mengatasi permasalahan siswa sebagai korban dan pelaku sehingga terbentuk perilaku positif siswa SD yang diharapkan (GoodmanScott, et, all., 2013).

Masih terdapat ruang yang belum dijelaskan dalam hasil studi terdahulu, yaitu: persentase antara korban dan pelaku, perbedaan perilaku kekerasan antara siswa berdasarkan jenis kelamin dan tingkatan kelas, tidak ada penjelasan bagaimana korban-pelaku terbentuk, belum ada pembahasan mengenai faktor internal penyebab perilaku kekerasan, dan 
tidak ada rumusan tentang intervensi berbasis nuansa sekolah (school-based climate intervention). Maka tujuan dari penelitian ini adalah: (1) mengidentifikasi siswa yang memiliki perilaku kekerasan, bentuk-bentuk perilaku kekerasan siswa, dan korban perilaku kekerasan; (2) menjelaskan perbedaan perilaku kekerasan antara siswa kelas rendah dengan siswa kelas tinggi; dan antara siswa laki-laki dengan perempuan; (3) menemukan faktor internal (diri pribadi) penyebab terbentuknya perilaku kekerasan siswa; dan (4) mengetahui peran guru SD dalam mengatasi perilaku kekerasan siswa yang berbasis nuansa sekolah. Dengan hasil penelitian ini guru akan mengetahui berapa banyak siswa yang melakukan tindak kekerasan, apa saja tindak kekerasan yang dilakukan siswa, tindak kekerasan mana yang memiliki efek terkecil hingga yang paling serius bagi korbannya untuk kemudian dapat mengatasi masalah perundungan di sekolah baik pada pelaku maupun pada korbannya dan melakukan pencegahan yang lebih komprehensif dengan mengetahui faktor-faktor resiko pada korban dan pelaku.

\section{Metode}

Penelitian ini dilaksanakan di SDN Lenteng Timur, Kecamatan Lenteng, Kabupaten Sumenep dengan menggunakan jenis penelitian mixed-method desain berurutan (kuantitatif $\rightarrow$ kualitatif). Dengan desain ini peneliti melakukan studi kuantitatif dan kualitatif secara berurutan; penelitian kuantitatif diselesaikan terlebih dahulu, setelah mendapatkan hasilnya ditindaklanjuti dengan penelitian kualitatif. Rancangan penelitian dapat dilihat pada gambar 1 (Creswell, 2006).

Desain mixed method berurutan atau disebut juga explanatory design merupakan penelitian yang memiliki dua fase pengumpulan dan analisa data (Creswell, 2006). Desain ini diawali dengan pengumpulan dan analisa data kuantitatif sebagai fase pertama, kemudian fase pertama diikuti oleh pengumpulan dan analisa lanjutan berupa data kualitatif. Metode kualitatif sebagai fase kedua dalam desain penelitian masih berhubungan dengan hasil analisa data pada fase pertama. Karena penelitian ini diawali dengan metode kuantitatif maka penelitian kualitatif sebagai fase runtutan di tahap kedua hanya bisa dilakukan setelah menyelesaikan seluruh kegiatan metode kuantitatif karena metode kualitatif digunakan untuk menjelaskan lebih dalam mengenai hasil penelitian kuantitatif.

\section{Partisipan Penelitian}

Partisipan penelitian adalah siswa kelas rendah dan siswa kelas tinggi dari SDN lenteng Timur. Teknik penentuan sample penelitian kuantitatif menggunakan cluster sampling, maka didapatkan 6 kelompok sampel: kelas IB, IIA, dan IIIC (kelas rendah) dan IVA, VB, dan VIA (kelas tinggi) yang kesemuanya berjumlah 142 siswa.

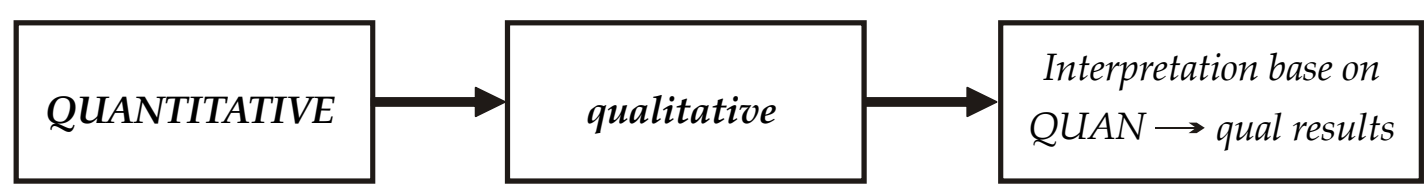

Gambar 1. Explanatory Design 
Responden dalam penelitan kualitatif ditentukan setelah peneliti mendapatkan hasil asesmen perilaku kekerasan siswa. Berdasarkan data identitas perilaku kekerasan terpilih 6 siswa masing-masing dari kelas yang menjadi bagian dari kelompok sampel. Kemudian wali kelas dan kepala sekolah juga digunakan sebagai partisipan agar diperoleh data kulitatif yang lebih komprehensif. Sementara objek penelitiannya ialah perilaku kekerasan siswa yang ditunjukkan di sekolah.

\section{Prosedur Penelitian}

Fase Pertama

Penelitian dilakukan berdasarkan desain yang telah ditentukan, yaitu mengacu pada two-phase of explanatory design. Langkah pertama ialah melakukan penelitian dengan metode kuantitatif untuk dapat mengindentifikasi perilaku kekerasan siswa beserta bentuk perilakunya dan siapa korban kekerasan tersebut. Dan juga untuk menjelaskan perbedaan perilaku kekerasan antar siswa yang dibedakan atas perbedaan jenis kelamin dan tingkatan kelas rendah (1-3) dan kelas tinggi (4-6) yang ada di sekolah. Data yang berhubungan dengan identifikasi perilaku kekerasan dan perbedaan perilaku kekerasan diperoleh melalui pengisian angket perilaku kekerasan berupa "the National School Safety Centeris (NSSC's) Checklist" yang telah disahkan oleh American Department of Education dan American Department of Justice (Sciarra, 2004).

Hasil penelitian mengenai identitas siswa pelaku kekerasan, siswa korban perilaku kekerasan, dan bentuk-bentuk perilaku kekerasan diperoleh melalui analisa data deskriptif kuantitatif. Untuk analisa data perbedaan perilaku kekerasan antara siswa laki-laki dan perempuan menggunakan independent sample t-test, begitu pula dengan perbedaan perilaku kekerasan antara siswa kelas rendah dan siswa kelas tinggi.

\section{Fase Kedua}

Saat peneliti melakukan kegiatan penelitian fase kedua menggunakan metode kualitatif, hasil analisa data kuantitatif sudah diperoleh, yaitu: (1) teridentifikasi jumlah siswa yang pernah menjadi pelaku kekerasan; (2) diketahui terdapat 15 bentuk kekerasan yang dilakukan siswa; (3) diperoleh juga jumlah siswa yang menjadi korban kekerasan di sekolah; (4) terdapat perbedaan perilaku kekerasan antara siswa kelas rendah dan siswa kelas tinggi; dan (5) terdapat perbedaan perilaku kekerasan antara siswa laki-laki dan siswa perempuan. Dari hasil tersebut belum diketahui faktor penyebab perilaku kekerasan, maka untuk menemukan faktor penyebab terbentuknya perilaku kekerasan dilaksanakanlah prosedur penelitian kualitatif dengan metode pengumpulan data wawancara terhadap siswa, wali kelas, dan kepala sekolah.

Selain itu, studi mengenai kekerasan reaktif di sekolah tempat penelitian ini dilangsungkan, perlu diketahui pula bagaimana peran guru dalam upaya pencegahan dan tindak pengentasan masalah perundungan. Karena itu sekali lagi wawancara dilakukan dengan wali kelas dan kepala sekolah SDN Lenteng Timur. Sebagai penguat data hasil wawancara kemudian metode observasi digunakan untuk memahami salah satu faktor penyebab perilaku kekerasan, yaitu lingkungan sekolah.

\section{Teknik Pengumpulan dan Analisa Data}

Data kuantitatif diperoleh dengan penggunaan angket perilaku kekerasan yang disusun berdasarkan kategori perilaku kekerasan dalam NSSC's Checklist. Instrumen tersebut diisi oleh kelompok 
sampel di dalam kelas masing-masing. Khusus untuk kelompok sampel dari kelas rendah pengisian angket dipandu oleh wali kelas dan penulis agar tidak terjadi kekeliruan dalam memahami kalimat dan cara mengisi angket. Analisa data kuantitatif dilakukan dengan bantuan SPSS 16.0 for Windows. Selanjutnya hasil pengisian dan analisis angket dijadikan data untuk melakukan penelitian kualitatif.

Data kualitatif didapatkan dengan metode observasi dan wawancara. Wawancara dilakukan pada responden, teman dari responden, dan wali kelas. Sementara kegiatan observasi meliputi kegiatan pembimbingan wali kelas pada siswa dan siswi asuhnya dan penulusuran lokasi-lokasi sekolah dan sekitarnya yang rawan dijadikan lokasi tindak kekerasan. Analisa data kualitatif menggunakan analisis model Miles dan Huberman.

\section{H a s i 1}

\section{Identitas Perilaku Kekerasan Siswa}

Dari 142 siswa, terdeteksi $62.761 \%$ siswa pernah melakukan tindak kekerasan dan $37.323 \%$ yang tidak melakukan kekerasan. Persentase tersebut diklasifikasikan berdasarkan kelas rendah, kelas tinggi, siswa perempuan (kelas rendah dan kelas tinggi), dan siswa laki-laki (kelas rendah dan kelas tinggi).

Persentase pada gambar 2 tidak berarti bahwa para siswa memiliki atau melakukan semua bentuk tindak kekerasan. Pada tabel 1 berikut dapat dilihat bentuk-bentuk perilaku kekerasan siswa, baik ucapan maupun tindakan.

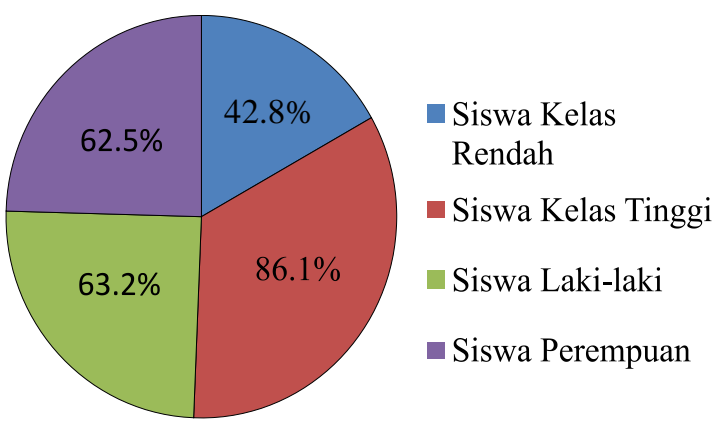

Gambar 2. Persentase siswa pelaku kekerasan

Tabel 1

Bentuk Perilaku Kekerasan Siswa

\begin{tabular}{ll}
\hline \multicolumn{1}{c}{ Bentuk Perilaku Kekerasan } & \multicolumn{1}{c}{ Jenis Perilaku } \\
\hline Suka mengamuk dan memiliki emosional tak terkendali saat marah & Kekerasan Fisik \\
Mengolok-olok, mencaci-maki, dan menggunakan bahasa kasar & Kekerasan Verbal \\
Menyakiti teman saat marah & Kekerasan Fisik \\
Pelanggaran disiplin sekolah & Kekerasan Sikap \\
Mencoba mengonsumsi rokok & Kekerasan Sikap \\
Senang pada senjata tajam, bahan peledak, dan bahan berbahaya lainnya & Kekerasan Sikap \\
Membolos & Kekerasan Sikap \\
Sering dikeluarkan dari kelas & Kekerasan Sikap \\
Menyiksa binatang & Kekerasan Fisik \\
Menindas teman (mengancam, meminta uang, mengucilkan, diskriminatif) & Kekerasan Fisik \\
Melimpahkan kesalahan pada teman & Kekerasan Verbal \\
Meniru adegan kekerasan di televisi & Kekerasan Fisik \\
Mengekspresikan kemarahan dalam bentuk tulisan/ coretan di buku/ tembok & Kekerasan Sikap \\
Bergabung dengan anggota gang sekolah & Kekerasan Fisik \\
Memiliki mood swings (tempramental) yang signifikan & Kekerasan Fisik \\
\hline
\end{tabular}


Pada gambar 3 terdapat data jumlah siswa (dalam bentuk persentase) yang menjadi korban kekerasan:



Gambar 3. Korban Perilaku Kekerasan

Bentuk-bentuk tindak kekerasan yang diterima oleh korban berupa: 1) Dijauhi/ dimusuhi/tidak diajak bicara/tidak dilibatkan dalam kelompok oleh teman, 2) Diganggu/dipukul/diolok-olok/dicaci/ dimintai uang secara paksa/dicubit/ digigit oleh teman atau kakak kelas, 3) Diancam oleh teman

Perbedaan Perilaku Kekerasan Siswa Kelas Rendah dengan Kelas Tinggi

Hasil pengisian angket oleh siswa diolah dengan SPSS 16.0, perolehan nilai angket antara kelas tinggi dan kelas rendah dinalisis dengan independent sample t-test, berikut pada Tabel 2 adalah output hasil analisis datanya.

Tabel 2 ini menunjukkan nilai signifikansi perilaku kekerasan 0.000 dan nilai signifikansi kelas (rendah dan tinggi) 0.000. Kedua nilai tersebut lebih kecil dari 0.05, maka dapat disimpulkan bahwa datanya berdsitribusi tidak normal.

Dari tabel 3 dapat diketahui bahwa signifikansi sebesar 0.004. Karena signifikansi kurang 0.05 maka kesimpulannya adalah dua kelompok data perilaku kekerasan berdasar kelas rendah dan tinggi mempunyai varian yang berbeda, atau dengan kata lain kelompok data tidak homogen. Perbedaan perilaku kekerasan berdasarkan kelas rendah dan tinggi menggunakan non-parametric test.

Hipotesis yang diajukan yaitu, $\mathrm{H}_{0}$ : Tidak ada perbedaan perilaku kekerasan antara siswa kelas rendah dengan siswa kelas tinggi, dan $\mathrm{H}_{\mathrm{a}}$ : Ada perbedaan perilaku kekerasan antara siswa kelas rendah dengan siswa kelas tinggi. Oleh karena nilai $\mathrm{P}$ value $(0.000<0.05)$ maka $\mathrm{H} 0$ ditolak. Jadi diperoleh hasil bahwa ada perbedaan perilaku kekerasan antara siswa kelas tinggi dengan siswa kelas rendah.

Tabel. 2

Tests of Normality

\begin{tabular}{|c|c|c|c|c|c|c|}
\hline & \multicolumn{3}{|c|}{ Kolmogorov-Smirnova } & \multicolumn{3}{|c|}{ Shapiro-Wilk } \\
\hline & Statistic & df & Sig. & Statistic & df & Sig. \\
\hline PerilakuKekerasan & .182 & 142 & .000 & .938 & 142 & .000 \\
\hline Kelas & .362 & 142 & .000 & .634 & 142 & .000 \\
\hline
\end{tabular}

Tabel. 3

Test of Homogeneity of Variances

\begin{tabular}{lccc}
\hline \multicolumn{4}{c}{ PerilakuKekerasan-Siswa } \\
\hline Levene Statistic & df1 & df2 & Sig. \\
\hline 8.634 & 1 & 140 & .004 \\
\hline
\end{tabular}


Tabel 4.

Test Statisticsa

\begin{tabular}{llc}
\hline & & Perilaku Kekerasan-Siswa \\
\hline Most Extreme Differences & Absolute & .556 \\
& Positive & .556 \\
& Negative & .000 \\
Kolmogorov-Smirnov Z & & 3.299 \\
Asymp. Sig. (2-tailed) & & .000 \\
\hline
\end{tabular}

Perbedaan Perilaku Kekerasan Siswa Perempuan dan Siswa Laki-laki

Tabel 5

Independent Samples Test

\begin{tabular}{lll}
\hline & & P.Kekerasan-Siswa \\
\cline { 3 - 3 } Levene's Test for Equality & $\mathrm{F}$ & 2.225 \\
of Variances & $\mathrm{Sig}$. & .138 \\
t-test for Equality of Means & $\mathrm{t}$ & -.088 \\
& $\mathrm{df}$ & 140 \\
& Sig. (2-tailed) & .930 \\
& & \\
\hline
\end{tabular}

Uji F dilakukan melalui perbandingan probabilitas/signifikansi ialah nilai $P$ value $(0.138>0.05)$ maka H0 diterima (kedua varian sama) maka uji $\mathrm{t}$ menggunakan equal variances assumed.

\section{Independent Sample t Test}

$\mathrm{H}_{0}$ : Tidak ada perbedaan perilaku kekerasan antara siswa laki-laki dengan siswa perempuan, dan $\mathrm{H}_{a}$ : Ada perbedaan perilaku kekerasan antara siswa laki=laki dengan siswa perempuan. Melalui tabel 5 didapat nilai $t$ hitung (equal variance assumed) adalah -0.088 . Kemudian tabel distribusi t dicari pada $\alpha=5 \%: 2=2.5 \%$ (uji 2 sisi) dengan derajat kebebasan (df) n2 atau $142-2=140$. Dengan pengujian 2 sisi (signifikansi $=0.025)$ hasil diperoleh untuk $\mathrm{t}$ tabel sebesar 1.977.

Kriteria Pengujian: H0 diterima jika -t tabel $<\mathrm{t}$ hitung $<\mathrm{t}$ tabel dan $\mathrm{H} 0$ ditolak jika -t hitung $<-t$ tabel. Berdasar proba- bilitas $\mathrm{H} 0$ diterima jika $\mathrm{P}$ value $>0,05$ dan $\mathrm{H} 0$ ditolak jika $\mathrm{P}$ value $<0,05$. Oleh karena nilai -t hitung $<-t$ tabel $(-(-0.088)<-1.977)$ dan $\mathrm{P}$ value $(0.930>0.05)$ maka $\mathrm{H} 0$ ditolak. Maka diperoleh hasil bahwa ada perbedaan perilaku kekerasan antara siswa lakilaki dengan siswa perempuan.

\section{Diskusi}

Identitas Perilaku Kekerasan Siswa

Selama ini masih banyak pihak yang beranggapan bahwa perilaku kekerasan adalah perilaku yang membuat korbannya sakit ataupun terluka secara fisik. Padahal siswa sebagai manusia merupakan sosok yang terdiri dari dimensi fisik dan psikis, yang keduanya dapat tersakiti dan mengalami trauma. Baik itu reaksi fisik maupun rangkaian ucapan jika dilakukan untuk merendahkan, menghina, dan mendiskriminasi orang lain, maka 
dampaknya adalah rasa sakit; sakit fisik jika mendapatkan pukulan dan sakit psikis jika diejek melalui kalimat-kalimat kasar dan penuh ancaman.

Sebanyak $62.761 \%$ siswa SDN Lenteng Timur pernah melakukan perundungan di sekolah, baik kelas rendah maupun kelas tinggi, baik siswa laki-laki maupun perempuan. Penulis mendapatkan keterangan bahwa bentuk kekerasan yang pernah dilakukan berupa memukul, mencubit, menendang, merusak atau melemparkan benda dilakukan oleh pelaku baik kepada teman maupun adik kelas di lingkungan sekolah dan juga dilakukan pada binatang yang mengancam maupun tidak mengancam keberadaan siswa. Terdapat siswa yang suka mengikat (dibuat mainan) binatang sampai mati, atau langsung membunuhnya walaupun binatang tersebut tidak mengganggu. Sedangkan kekerasan verbal berupa ejekan (sering kali mengejek nama orang tua), sindiran, menggunakan bahasa kasar dan berteriak pada teman. Dan bentuk penindasan seperti meminta uang dan mengancam korban agar tidak melapor pada guru.

Fenomena ini, bagi pihak tertentu masih dinilai sebagai tindakan anak-anak (siswa) yang wajar dan tidak melewati batas. Padahal jika pada masa kanakkanak atau remaja kerap melakukan tindak kekerasan maka pada saat dewasa mereka menjadi pelaku tindak kriminal bahkan kekerasan seksual (Sciarra, 2004; Gibson \& Mitchell, 2010; Zwierzynska, dkk., 2013; Morcillo, dkk., 2015; Beattie, 2015). Dan yang lebih pedih adalah apa yang dirasakan oleh korban, karena selama masa SD selalu mendapatkan perlakuan dan ucapan kasar, maka sampai usia dewasa cenderung menjadi pribadi yang tertutup, tidak percaya diri, dan merasa tidak memiliki kelebihan apapun. Hiperaktif, perilaku agresi, perilaku- perilaku yang mengacu pada perilaku kekerasan, dan berbagai perilaku antisosial merupakan pertanda adanya kekerasan pada anak-anak.

\section{Perbedaan Perilaku Kekerasan Antar Siswa}

Siswa kelas tinggi dan siswa kelas rendah memang memiliki karakterisktik yang berbeda, persentasenya $86.153 \%$ (kelas tinggi) dan $42.857 \%$ (kelas rendah) yang melakukan perundungan. Dari kelas rendah, siswa kelas 1 tidak ada yang pernah melakukan perundungan pada teman, berbeda dengan kelas 2 dan kelas 3 yang mulai menjadi pelaku kekerasan di lingkungan sekolah. Sedangkan pada siswa kelas tinggi baik kelas 3, 4, dan 5 semakin banyak siswa yang melakukan kekerasan verbal maupun fisik. Inilah yang dimaksud oleh Majcherova, dkk. (2014) bahwa praktik kekerasan di sekolah semakin bertambah dan meluas, fenomena ini merupakan awal dari terbentuknya pure victim menjadi korban-pelaku, karena terdapat cyclical process antara faktor resiko dengan terbentuknya pure victim dan korban-pelaku (Juvonen \& Graham, 2014; Veenstra, dkk., 2013).

Siswa kelas rendah belum banyak yang memiliki keinginan untuk membentuk kelompok/gang, belum banyak terpengaruh oleh perilaku teman sebaya, masih membawa atmosfir TK-nya dalam tahap adaptasi di SD (terutama kelas 1), dan lebih berfokus pada pengembangan cara belajar di SD seperti belajar menulis dengan rapi, melatih kelancaran membaca, mengasah pemahaman terhadap kalimat, mengasah kemampuan dasar-dasar menghitung, dan lainnya. Sedangkan pada siswa kelas tinggi, para siswa sudah menyadari keterlibatan diri sebagai anggota dari lingkungan sekolahnya, mengembangkan kemampuan belajar dari kemampuan dasar yang telah dikuasai, 
merasa dapat berbuat banyak hal bersama teman dan pada adik kelas, merasa siswa senior yang ditakuti adik kelas ataupun teman yang dinilai lemah, dan terpenting adalah siswa kelas tinggi (terlebih kelas 5 dan 6) berada pada tahap usia kanakkanak akhir yang akan segera beralih pada masa remaja awal, sehingga banyak siswa perempuan yang mengalami menstruasi dan siswa laki-laki yang mulai berubah suaranya, serta diikuti oleh beberapa perubahan fisik lainnnya. Cook, Williams, Guerra, Kim, \& Sadek (2010) menjelaskan bahwa perubahan drastis fungsi sosial dan biologis terjadi saat individu berada pada masa transisi dari anak-anak menuju remaja. Akibat dari beberapa perubahan fisik itu, siswa kelas tinggi sudah mulai memperhatikan penampilan; bahkan merubah gaya berpakaian, semakin tertarik untuk bergabung dalam kelompok dan menjalankan aturan-aturan kelompok, dan dapat selalu membangkang jika dihadapi dengan cara yang kasar oleh guru.

Antara siswa perempuan dan siswa laki-laki, terdapat perbedaan bentuk perundungan antara keduanya. Hasil penelitian ini sejalan dengan penelitian yang dilakukan oleh Nansel dkk., 2001 dalam (Milsom \& Gallo, 2006) yang menyatakan bahwa terdapat perbedaan perilaku perundungan yang ditunjukkan oleh siswa laki-laki dan siswa perempuan Sekolah Dasar. Siswa laki-laki lebih lebih tertarik pada kegiatan fisik dan tertantang untuk menunjukkan agresivitasnya dengan asumsi maskulinitas (Gini \& Pozzoli, 2006).

Hasil studi ini melengkapi studi yang telah dilakukan Veenstra, dkk. (2013) yang menyatakan siswa laki-laki lebih banyak melakukan kekerasan dibandingkan siswa perempuan, yang kemudian dalam penelitian ini dilengkapi dengan jenis perilaku antara keduanya, bahwa siswa laki-laki lebih banyak melakukan kekerasan fisik dibandingkan dengan siswa perempuan. Sedangkan siswa perempuan lebih banyak sebagai pelaku kekerasan verbal, karena perempuan cenderung mengungkapkan kekecewaan, kemarahan, atau kesalahan secara lisan, dan juga karena adanya penilaian yang melekat pada perempuan bahwa mereka tidak pantas melakukan kegiatan fisik yang kasar, terlebih memukul ataupun menendang.

\section{Pelaku dan Korban Perilaku Kekerasan}

Siswa laki-laki dan perempuan, siswa dari kelas rendah dan kelas tinggi, pernah melakukan kekerasan fisik maupun verbal, pernah menjadi korban kekerasan fisik maupun verbal, bahkan ada yang selalu melakukan perundungan dan ada yang selalu menjadi korban perundungan. Tidak hanya siswa laki-laki, namun siswa perempuan juga merupakan pelaku, namun dengan bentuk yang berbeda. Dan di sini tidak selamanya siswa hanya menjadi pelaku, atau dalam posisi sebagai korban saja. Terdapat juga siswa yang menjadi pelaku dan juga menjadi korban, atau ada yang awalnya menjadi korban, namun membuat perlawanan/pembalasan dengan menjadi pelaku, secara langsung, maupun berproses.

Bila penelitian sebelumnya hanya menjelaskan tentang pelaku dan korban kekerasan antara siswa laki-laki dan perempuan dan rentang usia (Camodeca, dkk., 2002; Sciarra, 2004; Gini \& Pozzoli, 2006; McAdams \& Schmidt, 2007; Veenstra, dkk., 2013; Zwierzynska, dkk., 2013), maka dalam studi ini, selain juga mengangkat tentang perbedaan bentuk perundungan berdasarkan jenis kelamin, juga berfokus pada pelaku dan korban dengan klasifikasi kelas rendah dan kelas tinggi di SD, yang mana siswa kelas tinggi lebih banyak menjadi korban perun- 
dungan dari teman sebaya maupun dari kakak kelas.

Berdasarkan jenis kelamin siswa perempuan lebih banyak menjadi korban dibandingkan siswa laki-laki. Tidak hanya siswa laki-laki yang menjadi korban dari kekerasan fisik, namun siswa perempuan juga dilempar benda, mendapat pukulan, tendangan, cubitan dari siswa laki-laki. Namun siswa perempuan juga dapat membalas hal yang serupa pada siswa laki-laki, hal ini kerap terjadi antara teman. Pada kekerasan verbal lebih banyak dilontarkan oleh siswa perempuan pada siswa laki-laki.

Tindak perundungan ini tidak hanya terjadi antar individu/siswa, namun juga kerap terjadi antar kelompok/gang. Berdasarkan wawancara, hal yang sering memicu pertengakaran dan perundungan antara kelompok adalah saling mengejek nama orang tua dan mengejek kondisi fisik, seperti pendek, hitam, dan penampilan. Selain itu, biasanya antar kelompok ini menganggap bahwa kelompoknya lebih baik (keren) dari kelompok lain, sehingga saat bertemu, terutama saat istirahat para siswa akan saling mengunggulkan kelompoknya masing-masing dan saling mencibir kelompok lain. Bergabung dalam kelompok dianggap penting oleh sebagian siswa, karena siswa merasa diakui eksistensinya. Pada beberapa hal, kelompok menjadi wadah siswa untuk ikut-ikutan mengejek, mengancam, atau memukul siswa dari kelompok lain atau siswa yang bukan merupakan anggota kelompok manapun.

Dalam kaitannya dengan pelaku atau korban dan antara pelaku dan korban perundungan di SD, didapatkan kenyataan bahwa tidak semua korban akan selalu menjadi korban. Artinya, korban juga merupakan pelaku, atau yang pada awalnya korban, seiring berjalannya waktu juga dapat menjadi pelaku sebagai bentuk perlawanan atau pertahanan diri. Begitu pula dengan pelaku, dalam waktu tertentu dapat dalam posisi sebagai korban. Proses yang demikian mengakibatkan semakin banyak pelaku serta semakin banyak pula korbannya, dengan kata lain terjadi siklus kekerasan. Milsom \& Gallo (2006) menjelaskan tentang tentang perundungan reaktif, bahwa seseorang pelaku kekerasan, pada awalnya merupakan korban, kemudian mereka membuat respon dengan melakukan tindakan kekerasan juga. Jadi, yang perlu lebih diwaspadai adalah pelaku kekerasan, korban kekerasan, dan siswa yang pada awalnya sebagai korban namun pada akhirnya juga menjadi pelaku perundungan.

Fakor-faktor Diri Pribadi yang Memengaruhi Perilaku Kekerasan Siswa

Sebagian besar pelaku kekerasan seperti perundungan memiliki karakteristik psikologis khusus. Dan yang menjadi masalah serius ialah toleransi sekolah terhadap perilaku perundungan yang dilakukan siswa. Namun, pengaruh dari lingkungan keluarga juga tidak dapat dianggap remeh. Artinya, pelaku berasal dari sebuah rumah yang menerapkan perlakukan kasar, atau dengan kata lain, anak-anak mendapatkan perlakukan kasar dari anggota keluarganya, pengasuhan dan pendidikan yang tidak sepantasnya, dan rendahnya peran keluarga (Cook dkk., 2010; Majcherova, dkk., 2014). Sementara Hong dkk. (2014) menemukan bahwa setting lingkungan sekolah dapat dijadikan kesempatan bagi pelaku kekerasan untuk menyakiti korbannya, karena itu banyak penelitian tentang kekerasan anak di lingkungan sekolah. Jadi studi terdahulu juga membuktikan bahwa perilaku kekerasan antar siswa di sekolah disebabkan oleh "negative school climate" 
yang dapat meningkatkan kemungkinan terbentuknya keterlibatan perundungan.

Dari penjelasan mengenai faktor keluarga dan sekolah (termasuk teman sebaya), studi ini memberi tambahan penjelasan bahwa dari sisi siswa pribadi juga dapat membentuk perilaku kekerasan. Aksi intimidasi dan perlawanan merupakan bentuk atau cara siswa menghadapi tantangan hidup. Dengan melakukan kekerasan pada teman sebaya atau adik kelasnya, siswa merasa telah melakukan pertahanan diri.

Kondisi fisik yang kuat, keadaan ekonomi yang berkecukupan, dan siswa yang manja/diperlakukan over special akibat pola asuh orang tua, sering kali membuat siswa merasa dirinya dapat berkuasa, memiliki kendali terhadap teman-temannya, dan ingin dituruti segala perintahnya; perasaan dan kesadaran ini terbentuk dalam diri siswa yang kemudian terjadi penyalahgunaan kekuatan (Beattie, 2015) pada teman sebaya. Para siswa yang merasa dapat mengendalikan teman-temannya akan membentuk sebuah kelompok, dalam kelompok siswa tersebut tidak hanya untuk mencari teman, namun juga untuk mencari "pembantu" yang bisa disuruh untuk melakukan berbagai hal sesuai kehendaknya. Selain itu, sifat-sifat siswa seperti pemarah, memiliki ego yang tinggi, sering berbohong, ingin mendapatkan perhatian menjadi penyebab mengapa siswa mudah melakukan perundungan di sekolah.

\section{Model Intervensi Perundungan Berbasis Nuansa Sekolah (School-based Climate Intervention)}

Usaha Preventif Kepala Sekolah dan Wali Kelas

Salah satu hal yang ditonjolkan dalam pembelajaran kurikulum 2013 (K-13) adalah pembinaan dan penilaian sikap.
Kepala sekolah selaku pemimpin dan sosok utama di lingkungan sekolah dalam prosesi upacara pagi selalu menyampaikan secara lisan bahwa sikap-sikap terpuji seperti berkata jujur, perilaku disiplin, saling menolong, dan toleransi adalah nilai yang tidak kalah pentingnya dengan nilai raport. Selain itu kepala sekolah juga memberi contoh melalui tindakan seperti tidak berkata kasar pada siswa, datang tepat waktu ke sekolah, dan berkomitmen agar sekolah yang dipimpinnya menjadi contoh bagi sekolah lain dalam menerapkan K-13. Berkaitan dengan nilai sikap dan moral kepala sekolah memiliki prinsip untuk tidak memanipulasi data apa pun tentang sekolah dan tidak mau memberi sogok pada orang tua calon siswa agar mendaftarkan calon siswa ke SDN Lenteng Timur. Kepala sekolah juga memiliki fokus pada pengembangan keterampilan guru yang selain akan memberi kontribusi positif pada pengajaran, juga menambah keterampilan guru dalam membimbing para siswa.

Oleh karena K-13 ini memiliki beberapa perbedaan dengan Kurikulum Tingkat Satuan Pendidikan (KTSP) 2006 yang pada awal pembelajaran, wali kelas sebagai pembimbing menyampaikan bahwa aspek sikap akan lebih diperhatikan dan dinilai lebih serius oleh wali kelas. Selain itu, wali kelas membuat beberapa kesepakatan dalam pembelajaran dengan siswa, seperti konsekuensi yang akan diterima siswa bila tidak mengerjakan PR, bila melanggar disiplin, dan bila berkata bohong. Dengan membuat kesepakatan itu, wali kelas mengajak siswa agar memiliki komitmen, membangun kedisiplinan, dan berani bertanggung jawab atas perilakunya.

Dalam K-13 pembahasan materi tematik didesain secara berkelompok, jadi siswa akan berdiskusi dalam kelompok 
dan dengan anggota kelompoknya. Salah satu manfaat dari desain pembelajaran kelompok ini ialah agar siswa lebih berani mengungkapkan pendapat, siswa mampu bersosialisasi dengan seluruh teman kelasnya (karena kelompok tidak tetap), dan agar siswa yang pendiam dapat diterima oleh kelompok/teman kelasnya.

Mayoritas SD yang ada di Indonesia belum bekerja sama dengan psikolog atau konselor sekolah, termasuk SDN Lenteng Timur, walaupun sebenarnya peran konselor sekolah dapat memberikan dampak signifikan dalam penanganan perundungan dan membentuk perilaku positif di kalangan siswa SD (GoodmanScott, et, all., 2013). Oleh karena itu, wali kelas bertanggung jawab atas pengajaran dan bimbingan pada para siswanya. Dalam setiap kesempatan wali kelas selalu mengingatkan siswa pentingnya disiplin dan berkata jujur. Dan kepala sekolah sendiri, misalkan saat upacara sekolah selalu menekankan tentang sikap terpuji, disiplin, tekun belajar, mandiri, dan menjadi insan yang jujur.
Konseling oleh Wali Kelas

Banyak dari korban perundungan berada pada posisi terancam sehingga tidak berani untuk melaporkan tindakan pelaku pada wali kelas atau guru lainnya, maka wali kelas melakukan layanan konseling terbatas pada siswa yang terlihat sedang bertengkar (fisik maupun verbal). Dalam menangani masalah antar siswa, khususnya terkait perilaku kekerasan, wali kelas berusaha mendekatkan diri pada kedua pihak (pelaku maupun korban) dengan pertimbangan tidak ingin memihak pada siapapun sehingga siswa dapat menilai bahwa wali kelas tidak menyudutkan pelaku dan dapat melindungi korban dari ancaman berikutnya, wali kelas juga berusaha untuk tidak menggunakan kekerasan pada siswa dan melakukan pendekatan secara personal dengan menjalin komunikasi bersama siswa karena cara tersebut dinilai efektif; dapat merubah cara berpikir dan pola perilaku siswa.

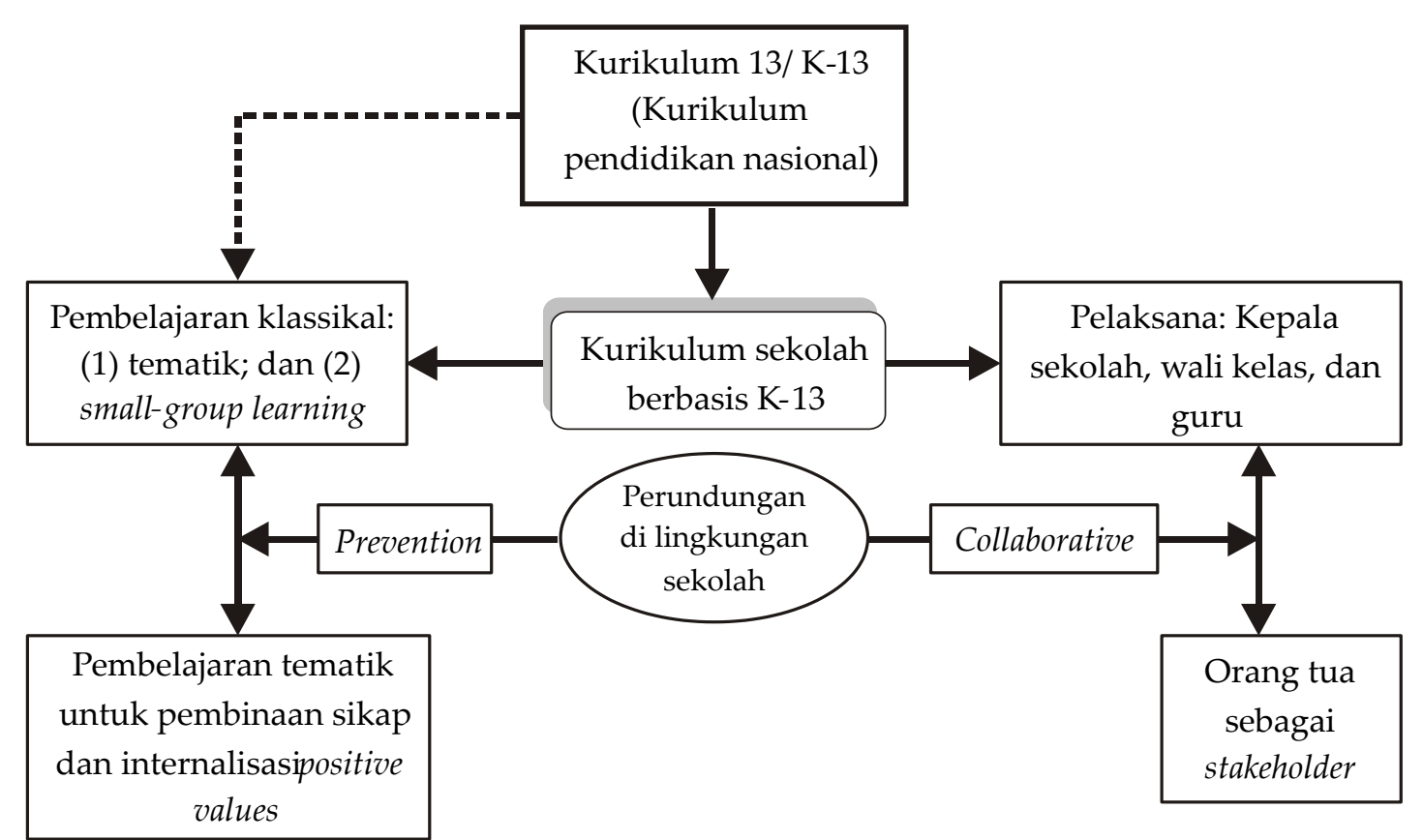

Gambar 4. Model Intervensi Kekerasan Berbasis Nuansa Sekolah 
Selain itu, sebelum menentukan bentuk pendekatan pada para siswanya, wali kelas terlebih dahulu memahami karakteristik siswa berdasarkan usia, kelas, jenis kelamin, latar belakang keluarga, serta pola perilaku siswa selama belajar di sekolah. Aspek-aspek tersebut akan sangat memengaruhi hubungan wali kelas dengan siswa dalam layanan konseling, karena jika wali kelas menyamakan pendekatakan antara siswa kelas rendah dengan siswa kelas tinggi, antara siswa perempuan dengan siswa laki-laki justru akan berakibat siswa tidak dapat mandiri, enggan mengakui kesalahan serta bertanggung jawab, merasa disalahkan oleh wali kelas, bahkan dapat semakin menjauh dari wali kelas.

Pendekatan yang dilakukan oleh wali disesuaikan dengan kondisi siswa, hal tersebut dianjurkan dalam pelaksanaan layanan konseling, yaitu mengenal diri siswa melihat latar belakang usia, perilaku, tahap perkembangan, jenjang kelas, dan sebagainya. Jika telah mengenal karakteristik siswa maka tentunya wali kelas dapat menyesuaikan bentuk pendekatan yang diprediksikan efektif dalam mengatasi perilaku kekerasan siswa di sekolah.

Wali kelas juga membicarakan masalah siswa pada orang tuanya (collaborative handling beetwen school and parent), karena pengawasan wali kelas sebagai guru hanya terbatas di lingkungan sekolah saja, selebihnya kembali pada perhatian orang tua terhadap anaknya di lingkungan keluarga. Peran dan tanggung jawab orang tua juga menjadi bagian dari proses intervensi untuk membantu mengurangi perundungan (Huang, dkk., 2013; Morcillo, dkk., 2015) karena salah satu penyebab perilaku kekerasan juga berasal dari lingkungan keluarga, misalnya siswa kurang mendapatkan perhatian dari kedua orang tua yang bekerja, membuat siswa mencari perhatian di sekolah dengan cara melakukan perundungan. Wali kelas, sesuai kapasitasnya, telah berupaya agar orang tua atau keluarga siswa mau diajak bekerjasama dalam membentuk perilaku yang baik.

\section{Kerjasama Wali Kelas dan Guru}

Wali kelas tidak bekerja sendiri, namun bimbingan dan layanan konseling juga terlaksana dengan adanya kerja sama (collaborative handling) antar guru (among teachers). Wali kelas sering kali melakukan kerjasama dengan guru Agama, PPKN, dan Olah Raga. Menurut salah satu wali kelas perempuan, siswa lebih segan jika berhadapan dengan guru laki-laki seperti guru Olah Raga atau guru Agama, jadi jika wali kelas merasa siswa belum dapat merubah perilakunya, maka wali kelas meminta guru Agama atau Olah Raga agar dapat ikut mengarahkan siswa pada perubahan perilaku yang lebih baik. Wali kelas juga meminta informasi dari wali kelas lainnya yang pernah membimbing siswa di kelasnya, misalkan wali kelas 4 meminta keterangan dari wali kelas 3 mengenai perilaku siswa pada saat berada di kelas 3. Karena wali kelas sebelumnya memiliki data mengenai kondisi siswa. Para wali kelas berbagi pengalaman dalam membimbing serta menangani berbagai perilaku siswa yang tidak adaptif, termasuk perilaku kekerasan, wali kelas meminta masukan dari wali kelas lainnya dan berbagi solusi yang pernah diberikan pada siswa-siswanya.

\section{Kelemahan Penelitian}

Hasil penelitian menunjukkan jumlah pelaku dan jumlah korban kekerasan. Namun dalam penelitian ini tidak diklasifikasikan jumlah pelaku untuk masingmasing kekerasan fisik, verbal, dan sikap. 
Begitu pun bagi korban, siapa yang hanya menerima satu bentuk kekerasan atau lebih.

Antara siswa kelas rendah dan siswa kelas tinggi terdapat perbedaan perilaku kekerasan, namun independent sample t-test yang digunakan adalah statistik non parametrik karena data terdistribusi tidak normal dan varian data tidak homogen. Hal ini terjadi karena saat pengisian checklist, siswa kelas rendah memiliki pemahaman yang belum memadai dibandingkan siswa kelas tinggi. Walaupun butir-butir checklist telah dibacakan dan dijelaskan (dengan bantuan Bahasa Madura) oleh peneliti dan wali kelas namun masih banyak siswa kelas rendah yang belum lancar membaca, belum sepenuhnya memahami maksud dari redaksi butir-butir checklist, belum terampil menuliskan identitas diri seperti usia, nama, kelas, dan jenis kelamin. Terutama siswa kelas 1 SD yang sulit dikondisikan saat pengisian checklist.

Keluarga merupakan salah satu faktor pembentuk perilaku kekerasan pada siswa, namun peneliti tidak melakukan wawancara pada orang tua atau keluarga siswa pelaku kekerasan dan juga tidak melakukan observasi di lingkungan keluarga. Karena itu penelitian ini tidak memiliki penjelasan mengenai apa yang terjadi dalam kehidupan keluarga siswa pelaku kekerasan dan bagaimana proses pembentukan perilaku kekerasan siswa yang dipengaruhi oleh interaksi kekerasan dalam keluarga.

\section{Kesimpulan}

Identitas siswa pelaku berdasarkan jumlahnya siswa laki-laki lebih banyak yang menjadi pelaku perundungan namun hanya terpaut $1.3 \%$ dengan siswa perempuan. Siswa perempuan cenderung melakukan perundungan secara verbal sementara siswa laki-laki dominan dalam perundungan secara fisik. Berdasarkan jenjang kelas teridentifikasi bahwa jumlah pelaku perundungan yang berasal dari siswa kelas tinggi jauh lebih banyak dibandingkan dengan siswa kelas rendah. Siswa kelas rendah hanya melakukan perundung pada teman sebayanya, sementara siswa kelas tinggi melakukan perundungan baik pada teman sebaya maupun pada adik kelasnya. Korban perundungan adalah mereka yang dianggap lemah, lebih muda, takut untuk memberi tahu pada guru dan tidak mampu membela diri. Kekerasan fisik, verbal, maupun sikap sama-sama diterima oleh korban; siswa perempuan lebih sering mendapatkan perundungan secara verbal sementara siswa laki-laki lebih banyak menerima perundungan secara fisik.

Siswa yang merasa memiliki kekuatan fisik, merasa pantas untuk mendapatkan perlakukan istimewa, merasa harus mendapatkan pelayanan dari orang lain, ditambah lagi dengan sifat manja dan pemarah merupakan faktor penyebab perilaku kekerasan yang berasal dari diri pribadi. Di sekolah siswa dapat menjadi pelaku perundungan karena pengaruh dari kelompoknya atas dasar mengikuti aturan kelompok atau mereka yang awalnya merupakan korban kemudian belakangan menjadi pelaku perundungan, inilah yang disebut dengan perundungan reaktif.

Upaya preventif, kuratif, dan pengawasan telah dilakukan oleh masingmasing pihak dengan cara kolaboratif antara kepala sekolah dengan wali kelas, wali kelas dengan guru mata pelajaran, wali kelas dengan orang tua, dan seterusnya. Bentuk bimbingan yang diberikan pada siswa disesuaikan dengan kebutuhan siswa sekaligus dikaitkan dengan materi 
pelajaran dan kurikulum sekolah, melalui strategi tersebut secara bertahap siswa dapat memahami bagaimana agar diri siswa dapat mengarahkan dirinya sendiri untuk berbuat baik pada sesama teman, selain itu para siswa pun menunjukkan kemauan bekerja sama dengan wali kelasnya saat mereka mengetahui ada temannya yang melakukan tindak kekerasan, hal ini membantu guru dan wali kelas untuk memberikan layanan bimbingan dan konseling lebih lanjut pada pelaku dan juga pada korban perundungan.

\section{Saran}

Perundungan di sekolah bukan fakta atau pun fenomena baru, namun permasalahan ini masih relevan untuk mendapat perhatian dan mendapatkan penanganan. Faktanya kekerasan terjadi bukan hanya di kalangan remaja, namun juga di kalangan anak usia sekolah dasar. Untuk itu dengan berlandaskan pada hasil penelitian ini peneliti memberi saran dalam tatanan praktis bagi segenap guru, wali kelas dan kepala sekolah untuk semakin peka terhadap tindakan dan perilaku perundungan di kalangan siswasiswi asuhnya. Bahwa kekerasan bukan hanya pukulan dan tendangan yang berdampak trauma fisik, melainkan sikap seperti memusuhi, menjauhi, mengasingkan, dan mendiamkan teman juga merupakan perilaku kekerasan sikap. Dan perkataan yang ditujukan untuk mengejek, mempermalukan, mengolok-ngolok dan menghina kondisi fisik, kemampuan intelektual, atau nama orang tua dari teman-temannya adalah bagian dari kekerasan verbal. Di mana kekerasan sikap dan kekerasan verbal ini cenderung memunculkan dampak psikis.
Perundungan tidak hanya mengenai perbedaan kondisi antara korban dan pelaku saja, namun juga ada proses yang lebih berbahaya yaitu terjadinya perundungan reaktif di lingkungan sekolah dari waktu ke waktu sehingga tindak kekerasan di sekolah sulit untuk terputus. Oleh karenanya selain telah mengupayakan layanan preventif melalui pembelajaran di ruang kelas dan pembimbingan di luar ruang kelas, guru, wali kelas, dan kepala sekolah seyogyanya memaksimalkan layanan yang bersifat kuratif pada korban dan pelaku sekaligus untuk memutus simpul-simpul perundungan reaktif di sekolah karena beberapa siswa pelaku kekerasan awalnya adalah korban kekerasan yang "merasa berhak" melakukan pembalasan fisik dan menyalurkan emosi akibat luka psikis dengan cara mengulang dan meniru tindakan kekerasan yang pernah diterimanya saat menjadi korban. Juga, antara posisi korban dan posisi pelaku bisa terjadi dalam waktu yang bersamaan atau beruntun seperti saling melakukan kekerasan antara ke dua belah pihak.

Tidak semua faktor resiko kekerasan dapat diatasi seutuhnya, namun sekurangkurangnya guru, wali kelas, dan kepala sekolah seyogyanya dapat memantau dan menyediakan solusi bagi faktor resiko terdekat, yaitu lingkungan sekolah karena masih ada beberapa titik yang siswa nilai aman dari pengawasan guru seperti halaman sekolah, area sekitar warung makanan, bahkan ruang kelas itu sendiri. Maka kemudian lokasi tersebut menjadi lokasi pilihan untuk melakukan perundungan kesekian kalinya.

\section{Kepustakaan}

Beattie, R.M. (2015). Long-term effects of bullying. Archieve of Disease in 
Childood, 100(9i). DOI: 10.1136/ archdischild-2015-309491.

Burton, K.A., Florell, D., \& Gore, J.S. (2013). Differences in proactive and reactive aggression in traditional bullies and cyberbullies. Journal of Aggression, Maltreatment \& Trauma, 22(3), 316-328. DOI: 10.1080/ 10926771.2013.743938.

Camodeca, M., Goossens, F.A., Terwogt, M.M., \& Schuengel, C. (2002). Bullying and victimization among school-age children: stability and links to proactive and reactive aggression. Social Development, 11(3), 332-345. DOI: 10.1111/1467-9507-00203.

Cook, C.R., Williams, K.R., Guerra, N.G., Kim, T.E., \& Sadek, S. (2010). Predictors of bullying and victimization in childhood and adolescence: A meta-analytic investigation. School Psychology Quarterly, 25(2), 65.

Creswell, J. (2006). Choosing a mixed method design. Sage: Thousand Oaks.

Dedousis-Wallace, A., Shute, R., Varlow, M., Murrihy, R., \& Kidman, T. (2014). Predictor of teacher intervention in indirect bullying at school and outcome of a professional development presentation for teachers. Educational Psychology, 34(7), 862-875. DOI: 10.1080/01443410.785385.

Gibson, R.L., \& Mitchell, M.H. (2010). Bimbingan dan konseling. Yogyakarta: Pustaka Pelajar.

Gini, G., \& Pozzoli, T. (2006). The role of maculinity in children's bullying. Sex Roles, 54(7), 585-588. DOI: 10.1007/ s11199-006-9015-1.

Golmaryami, F.N., Frick, P.J., Hemphill, S.A., Kahn, R.E., Crapanzano, A.M., \& Terranova, A.M. (2016). The Social, behavioral, and emotional correlates of bullying and victimization in a school- based sample. Journal of Abnormal Child Psychology, 44(2), 381-391. DOI: 10.1007/s10802-015-9994-x.

Goodman-Scott, E., Doyle, B., \& Brott, P. (2013). An action research project to determine the utility of bully prevention in positive behavior support for elementary school bullying prevention. Professional School Counseling, 17(1) 120-129. DOI: 10.5330/prsc.17.153346473u5052044.

Healy, K.L., Sanders, M.R., \& Lyer, A. (2015). Parenting practices, children's peer relationships and being bullied at school. Journal of Child and Family Studies, 24(1), 127-140. DOI: 10.1007/ s10826-013-9820-4.

Hong, J.S., \& Espelage, D.L., (2012). A review of research on bullying and peer victimization in school: An ecological system analysis. Aggression and Violent Behavior, 17(4), 311-322. DOI: 10.1016/j.avb.2012.03.003.

Hong, J.S., Peguero, A. A., Choi, S., Lanesskog, D., Espelage, D.L., \& Lee, N.Y. (2014). Social ecology of bullying and peer victimization of Latino and Asian youth in the United States: a review of the literature. Journal of School Violence, 13(3), 315-338.

Huang, H., Hong, J.S., \& Espelage, D.L. (2013). Understanding factors associated with bullying and peer victimazation in chinese schools within ecological contexts. Journal of Child and Family Studies, 22(7), 881-892. DOI: 10.1007/s10826-012-9647-4.

Juvonen, J., \& Graham, S. (2014). Bullying in School: The Power of Bullies and the Plight of Victims. Annual Review of Psychology, 65, 159-185. DOI: 10.1146/ annurev-psych-010213-115030.

Majcherova, K., Hajduova, Z., \& Andrejkovic, M. (2014). The role of the 
school in handling the problem of bullying. Aggression and Violent Behavior, 19(5), 463-465. DOI: 10.1016/ j.avb.2014.06.003.

McAdams, C.R., \& Schmidt, C.D. (2007). How to help a bully; recommendation for counseling the proactive aggressor. ASCA Professional School Counseling, 11:2, Desember, 120-128.

Milsom, A., \& Gallo, L.L. (2006). Bullying in middle schools: Prevention and intervention. Middle School Journal (J1), 37(3), 12-19.

Morcillo, C., Ramos-Olazagasti, M.A., Blanco, C., Sala, R., Canino, G., Bird, H., \& Duarte, Cristiane S. (2015). Socio-cultural context and bullying others in childood. Journal of Child and Family Studies, 24(8), 2241-2249. DOI: 10.1007/s10826-014-0026-1.

Morrow, M.T., Hubbard, J. A., \& Swift, L. E. (2014). Relations among multiple types of peer victimization, reactivity to peer victimization, and academic achievement in fifth-grade boys and girls. Merill-Palmer Quarterly, 60(3), 302-327.

Notosoedirdjo, M., \& Latipun. (2007). Kesehatan mental; konsep dan penerapan. Malang: UMM Press.

Olweus, D., \& Breivik, K. (2014). Plight of victims of school bullying: the opposite of well-being. Handbook of Child Well-Being, 15, 2593-2616. DOI: 10.1007/978-90-481-9063-8-100.

Puhl, R.M., \& King, K.M. (2013). Weight discrimination and bullying. Best Practice \& Research Clinical Endocri- nology $\mathcal{E}$ Metabolism, 27(2), 117-127. DOI: 10.1016/j.beem.2012.12.002.

Ramdhani, Neila. (2016). Emosi moral dan empati pada pelaku perundungan siber. Jurnal Psikologi, 43(1), 66-80. DOI: 10.22146/jpsi.12955.

Sciarra, D.T. (2004). School counseling; foundations and contemporary issues. USA: Thompson Learning, Inch.

Toblin, R.L., Schawartz, D., Gorman, A.H., \& Abou-ezzeddine, T. (2005). Socialcognitive and behavioral attributes of aggressive victims of bullying. Journal of Applied Developmental Psychology, 26(3), 329-346.

Taylor, S.E. (2006). Health psychology. New York: McGraw-Hill.

Veenstra, R., Verlinden, M., Huitsing, G., Verhulst, F. C., \& Tiemeier, H. (2013). Behind bullying and defending: samesex and other-sex relations and their associations with acceptance and rejection. Aggressive Behavior, 39(6), 462-471. DOI: 10.1002/ab.21495.

Yang, A., \& Salmivalli, C. (2013). Different forms of bullying and victimization: Bully-victims versus bullies and victims. European Journal of Developmental Psychology, 10(6), 723$738 . \quad$ DOI: $10.1080 /$ 17405629.2013.793596.

Zwierzynska, K., Wolke, D., \& Lereya, T.S. (2013). Peer victimization in childood and internalizing problems in adolescence: a prospective longitudinal study. Journal of Abnormal Child Psychology, 41(2), 309-323. DOI: 10.1007/s10802-012-9678-8. 